Vol. 7, No. 2, 2020

https://doi.org/10.23939/eem2020.02.022

UDC 657.1:658.34

JEL Classification Code M41, G20

T. Davydiuk

National Technical University “Kharkiv Polytechnic Institute”, Ukraine, Doctor, Professor

ORCID ID: 0000-0003-3990-5926

S. Syrtseva

Mykolayiv National Agrarian University, Ukraine, PhD, Associate Professor ORCID ID: 0000-0003-4824-3741

V. Endres

Mykolayiv National Agrarian University, Ukraine, Student

V. Nadraga

National Technical University "Kharkiv Polytechnic Institute”, Ukraine, Student

\title{
METHODOLOGICAL ASPECTS OF ACCOUNTING OF WARRANTY PROVISION IN ACCORDANCE WITH INTERNATIONAL FINANCIAL REPORTING STANDARDS
}

\begin{abstract}
In order to ensure that warranty repair and maintenance costs are included evenly in accordance with National Accounting Standards and International Financial Reporting Standards, entities are entitled to create provisions under warranty. Creation of such provisions allows to adjust the income and expenses for warranty repair and maintenance and to reasonably distribute expenses between the reporting periods, which helps to optimize the tax burden. The purpose of the article is to review the methodological aspects of accounting of warranty provisions in accordance with International Financial Reporting Standards. The achievement of the stated goal necessitated the following tasks: to disclose the nature and conditions of recognition of provisions for warranty in accordance with international accounting standards; to present the methodology for accounting in the accounting and tax accounting and financial statements of the provision for warranty in accordance with IFRS; to propose methods of calculating the warranty provisions to determine their main advantages and disadvantages. The main general scientific methods of research were the analysis (for conducting the research of the main essential characteristics of the research object and peculiarities of its functioning in the context of the topic of scientific
\end{abstract}

work). Analogy method, dialectical method and systematic approach were used to reflect the methodological approach to accounting and to show in the financial statements the provisions for warranty. Comparison method was used for evaluating the techniques for calculating warranty provision for entities that prepare IFRS financial statements.

Key words: provisions, warranty, IFRS, warranty period, accounting policy.

\section{Introduction}

The issue of compliance with warranty obligations, accounting for the costs of their implementation, as well as the creation of appropriate provisions becomes particularly important in today's conditions when the quality of products is one of the main competitive advantages in the market.

So, most business entities, both manufacturers and sellers, have an obligation to correct defects in goods related to their poor quality if they are found to be in the consumer's warranty period. For such entities, provisions under warranty is associated with appropriate warranty costs, the magnitude of 


\section{Methodological aspects of accounting of warranty provision in accordance with international...}

which varies greatly depending on the occurrence of the event - the fact of detection of a defect (breakdown, defect) of the product.

In order to ensure that warranty repair and maintenance costs are included evenly in accordance with National Accounting Standards and International Financial Reporting Standards, entities are entitled to create provisions for warranty. Creation of such guarantees allows to adjust the income and expenses for warranty repair and maintenance and to reasonably distribute expenses between the reporting periods, which help to optimize the tax burden.

The questions of the essence of warranty provision, the problems of expediency of creation at the enterprises, methods of calculation of various types of provision at the enterprises, recording on the accounts, disclosure of information in the financial statements, taxation of operations on the accrual and use of the provision of waranty have been investigated by such scientists as N. Voskalo [1], S. Demyanenko [2], N. Dzyubo [3], T. Zatoka [4], O. Panchenko [5], A. Sviridenko [6], Y. Slivka [7], L. Chizhevskaya [8] and others.

Despite considerable experience, the issues of accounting of provision of warranty according to International Financial Reporting Standards, including accounting policies, documentation, reporting, features of various techniques for calculating of provisions, remain unexplored.

The purpose of the study is to review the methodological aspects of accounting of warranty provision under the International Financial Reporting Standards.

\section{Recognition of Warranty Provisions}

According to $\S 10$ of IAS 37 "Provisions, Contingent Liabilities and Contingent Assets" provision is a liability of indefinite duration or amount [9]. The liability of the entity arises from past events, and its repayment is expected to result in the disposal of resources embodying economic benefits.

The main difference between provision and other types of liabilities is the uncertainty of the timing of the costs under which the provision is created and their amounts, while:

- in the case of trade payables, there is an obligation to pay the delivered goods within the terms stipulated by the contract and according to the provided invoices;
- there is an obligation to pay for a delivered product or service that has been received but not paid, has not been billed, or has not been formally agreed by the supplier. However, the uncertainty about the amount and timing of accruals is much less than in the case of provision.

For example, IAS 37 "Provisions, Contingent Liabilities and Contingent Assets" [9] stipulates that a so-called factual or constructive obligation may be the cause of a provision under warranty in addition to the legal obligation (obligation arising from legislative and regulatory acts).

A constructive obligation is an obligation that results from the actions of an entity when:

- the entity has informed the other parties that it will assume some responsibility in accordance with the procedure established by its past practice, published policies, or a sufficiently specific current statement;

- as a consequence, the entity has created a reasonable expectation from other parties that it will fulfill these obligations (paragraph 10 of IAS 37) [9].

An example of such a constructive obligation is the public acceptance of the warranty repair and replacement policy within a specified period after the goods have been sold.

Provision is recognized when three criteria are simultaneously fulfilled ( $\$ 14$ IAS 37):

- the entity has an obligation (legal or constructive) arising from a past event;

- it is likely that the fulfillment of this obligation will require the disposal of resources containing economic benefits;

- the amount of the liability can be estimated reliably.

Accordingly, recognition of warranty provision requires not only an existing obligation, but also a high (over $50 \%$ ) probability of disposing of resources embodying economic benefits to fulfill that obligation. Otherwise, the contingent liability will again be disclosed in the notes ( $\$ 23,86$ IAS 37).

Also, to recognize provision, one must be able to reliably estimate the estimated future outflow of resources to fulfill the obligation. On the one hand, the definition of provision indicates an uncertainty in the amount of the liability, and on the other hand, IAS 37 requires recognition of provision only when it is possible to estimate it reliably. Therefore, in order to recognize the provision, the business needs to understand what 


\section{T. Davydiuk, S. Syrtseva, V. Endres, V. Nadraga}

expenses it will take to meet its existing obligations. IAS 37 also provides appropriate guidance on the assessment of provision, in particular in $\$ \S 36-47$. According to $\S 36$, the amount recognized as provision should be the best estimate of the expenses required to settle an existing liability at the end of the reporting period. This best estimate is the amount that an entity would reasonably pay to settle a liability or transfer it to a third party at the end of the reporting period ( $\$ 37$ IAS 37).

The seller's warranty can be recognized as a provision if all three of these criteria are met (Fig. 1). If at least one of these criteria is not met, then the provision of warranty is not recognized.

Therefore, if an entity that sells goods assumes a guarantee (legal or factual) and in the future has to incur warranty costs, the entity is required to recognize the provision in accordance with IFRS.

The purpose of the provision for warranty in terms of accounting - compliance with the principle of prudence. Its essence is that the assets and income of the enterprise should not be overstated, and liabilities and expenses - low.

Therefore, if it is known that in the future an entity should bear the costs of performing its warranty obligations, it is necessary to recognize such costs in the accounting period when the undertaking has assumed the guarantee obligations. That is not to wait the actual implementation of costs. This procedure will ensure the accuracy of accounting and financial statements of the company.

\section{Seller's warranty}

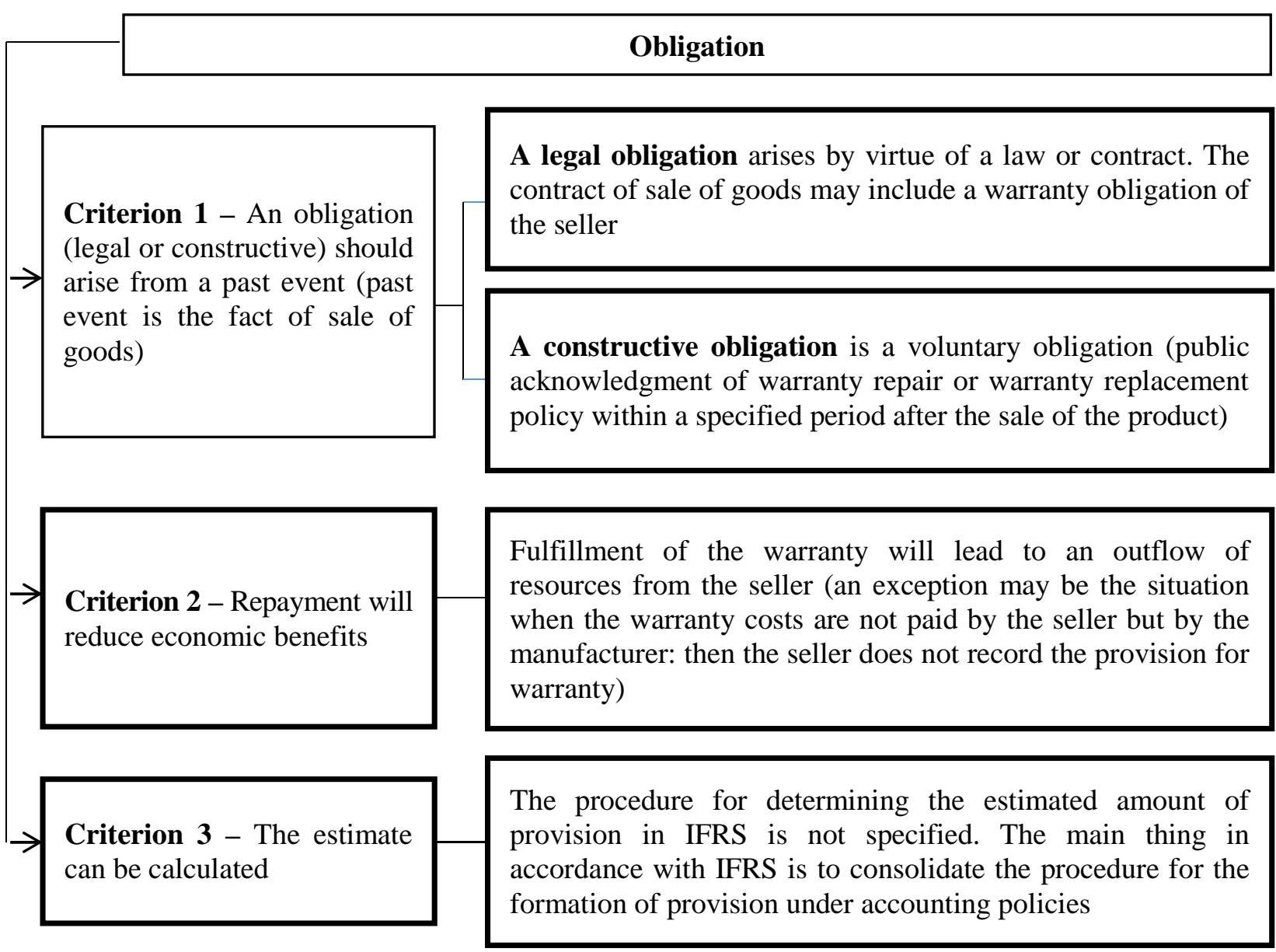

Fig. 1 . Criteria for recognizing the seller's warranty as provision under warranty

Source: created by the author. 


\section{Methodological aspects of accounting of warranty provision in accordance with international...}

The fact that the provision is calculated in advance, makes it possible to lay the planned amount of warranty costs in the price of products (goods). In this way, the entity receives reimbursement of the warranty costs "little by little" from each buyer and prevents losses [10].

Thus, there are three definite advantages to the recognition of provision, namely:

- this will allow the seller to evenly distribute the amount of warranty costs over time and put them into the price of the product;

- in the Balance, users will be able to see the estimated amount in the future of the entity's warranty costs for the goods sold;

- the statement of profit or loss will show users a more realistic amount of profit for the current period, given that some of the products sold may still have to incur warranty costs in the future.

\section{Recording of Warranty Provision in the Accounting and Reporting}

One of the peculiarities of accounting when recording operations in the performance of warranty obligations is the creation by the suppliers of goods of provision to recover the following (future) operating costs for the performance of warranty obligations.

IFRS does not oblige entities to develop any document that describes the accounting policies used.

However, developing such a document may protect the accountant from the claims of the head or owner of the entity; may be useful for audits of control entities; will be appropriate in disclosing accounting policies in the financial statements.
Therefore, in the accounting policy for accounting for warranty provision, the following should be recorded:

- Details of the future costs under which the provision is created. It should be kept in mind that warranty provision should be used only for the costs for which it was incurred ( $\$ 61$ IAS 37). For example, a provision set up for warranty TV repair cannot be used to cover the warranty costs of repairing mobile phones;

- directly the method of calculation of provision (for different products may differ - at the discretion of the entity);

- the frequency of accrual and review of the provision balance (at least once a year), the procedure for adjusting the security balance as a result of its review.

The amount of warranty provision is recognized as the cost of selling the period in which it was created.

Accounting of costs associated with the formation of warranty provision (Table 1).

During the reporting period, warranty costs are recorded against the balance of previously created provision. If such a balance is not sufficient, then the warranty costs in the amount of excess direct are included in the expenses of the period.

The provision for warranties should be reviewed at each reporting date (IFRS has a reporting period of one year) and, if necessary, adjusted for the same accounting entries that created the security (with the sign "+" in the direction of increase, with the sign "-" in the direction of decrease).

Table 1

Accounting of costs associated with the formation of warranty provision in accordance with IFRS

\begin{tabular}{|l|c|c|}
\hline \multicolumn{1}{|c|}{ Contents of the business operation } & \multicolumn{2}{c|}{ Corresponding Accounts } \\
\cline { 2 - 3 } & "Warranty costs" & "Warranty provision" \\
\hline Displaying the accrual of warranty provision & "Warranty provision" & "Inventory" \\
\hline $\begin{array}{l}\text { Spare parts for warranty repairs have been } \\
\text { written off }\end{array}$ & "Warranty provision" & "Accounts payable" \\
\hline $\begin{array}{l}\text { Wages for employees performing warranty } \\
\text { repairs have been calculated }\end{array}$ & "Warranty provision" & $\begin{array}{c}\text { "Social security contributions } \\
\text { payable" }\end{array}$ \\
\hline $\begin{array}{l}\text { Refunds to the payroll for employees performing } \\
\text { warranty repairs are recorded }\end{array}$ & "Warranty provision" & "Accounts payable" \\
\hline Accounts payable to third parties are recorded
\end{tabular}

Source: created by the author. 


\section{T. Davydiuk, S. Syrtseva, V. Endres, V. Nadraga}

With the adoption of IFRS 15 "Revenue from Contracts with Customers", another aspect of warranties provision has emerged.

Guarantees in connection with the sale of products (goods, works, services) may be provided by the terms of the contract, the law, the normal practice of conducting business of the entity.

The nature of warranty obligations in different industries and contracts may be significantly different. IFRS 15 "Revenue from Contracts with Customers" considers two types of guarantees [11]:

1) guarantees that reassure the customer that the product concerned will function as intended by the parties to the agreed specifications (so-called assurance-type warranties);

2) guarantees that provide the provision of a particular service in addition to assurance that the products meet the agreed specifications (so-called service-type warranties or extended warranties).

Thus, the assurance-type warranties are designed to protect the buyer from defects in the product. That is, in essence, they provide a guarantee of quality.

Assurance-type warranties do not imply the provision of additional service to the client. That is, such guarantees do not give rise to a separate performance obligation.

Costs incurred in connection with warranty repair or replacement of products are additional costs for the goods / services already promised to the customer. Such guarantees are accounted for in accordance with IAS 37 "Provisions, Contingent Liabilities and Contingent Assets" as provision for warranty repairs. But provided that the client does not have the opportunity to buy them separately. The estimated costs are recorded as a guarantee (provision) at the time the product is handed over to the customer by the company.

Under IFRS 15 , an entity provides a servicetype warranty if:

1) the customer has the opportunity to purchase the warranty separately. For example, because the guarantee or its price is negotiated separately (§ B29);

2) the warranty or part thereof provides for the provision of the service to the customer in addition to the assurance that the products meet the agreed specifications (§ B32).

Such a guarantee is a separate service, as the company promises to provide it to the customer in addition to the product whose functionality is described in the contract. Accounts for the promised warranty service as a performance obligation. Therefore, part of the transaction price is allocated to such an additional service.

If an undertaking promises both an assurance-type warranties and a service-type warranties but cannot reasonably account for them separately, then these guarantees are accounted together as the only performance obligation.

The algorithm for determining the type of guarantee is presented in Fig. 2.

In order to identify whether the customer (buyer) is able to purchase the warranty separately, the following factors must be considered:

1) Is a warranty required by law? If the company is required by law to provide a guarantee, then this is a normal guarantee - an assurance-type warranties. It does not have a separate obligation to comply, as such legal requirements generally exist to protect customers from the risk of purchasing defective products;

2) the length of the warranty period. The longer the warranty period, the more likely that the promised guarantee is the service-type warranties;

3) the nature of the tasks that the company promises to perform. If a business needs to complete certain tasks to assure that the products meet the agreed specifications, then they are likely not to cause compliance obligations. That is a guarantee-assurance [12]. Supporting L. Chizhevskaya's opinion, this approach will allow to identify all the factors that influence the decision to recognize revenue [8].

With regard to tax accounting, for payers of income tax, whose annual income for the last tax year exceeded UAH 20 million, clause 139.1 of Article 139 of the Tax Code of Ukraine provides for adjustments of provision to recover the following (future) expenses, including guarantees [13].

These adjustments should be made as shown in Fig. 3. 
Methodological aspects of accounting of warranty provision in accordance with international...

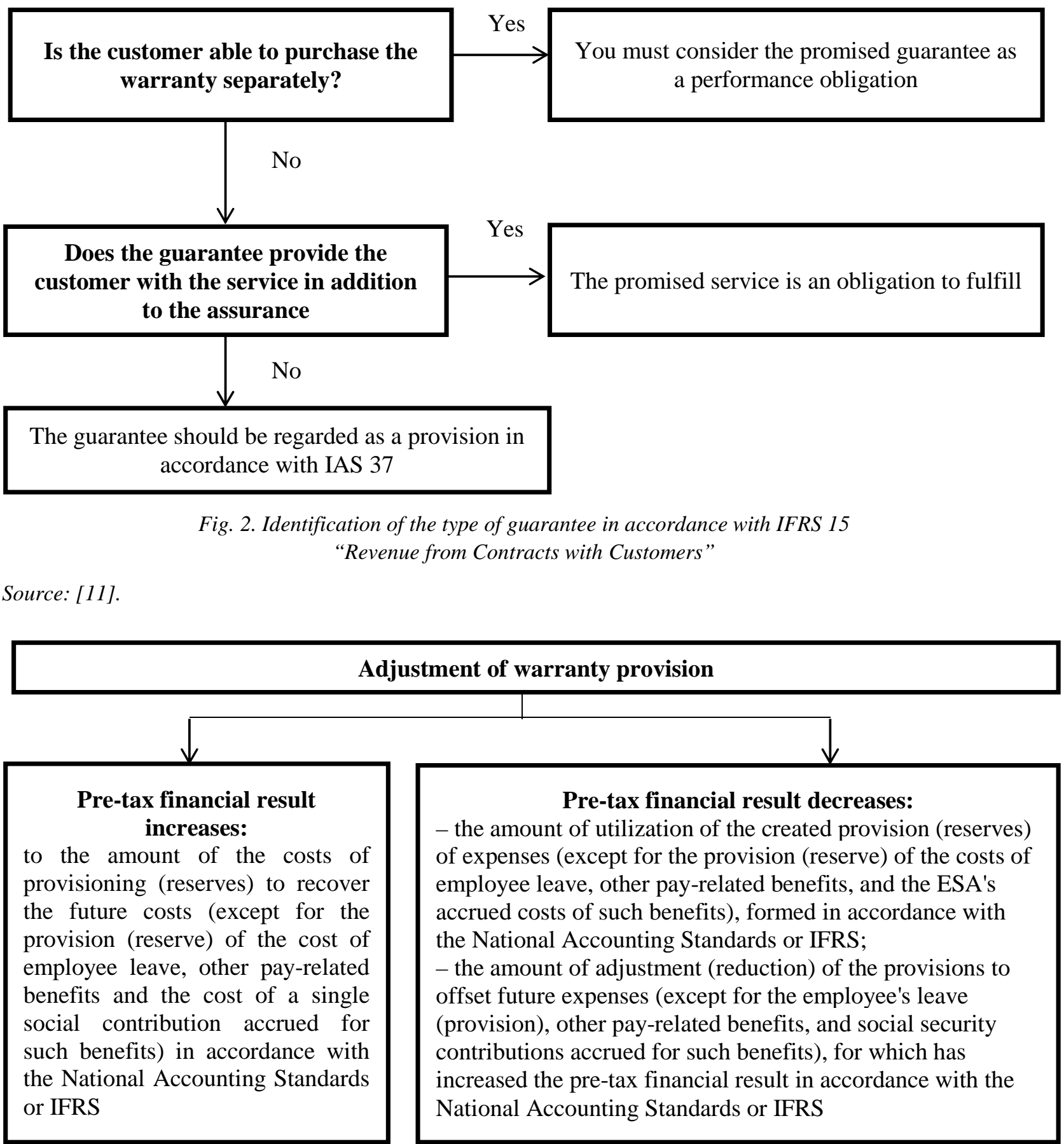

Fig. 3. Adjustment of warranty provisions in taxation

Source: [12].

The calculation of the amount of warranties provision obligations should be made by accounting. But if the provision for a certain period is fixed and approved in accounting policy or other regulatory documents, then the accounting information may not be issued.

In the Balance Sheet, the warranties provision balance should be recorded in current and/or long- term liabilities, depending on how long the entity provides guarantees: up to or over one year. In the income statement, warranty costs are included in sales expenses.

\section{Methods of Calculation of Provision for Warranty}

The procedure of calculation of warranties provision in IAS 37 is not defined, so the method 


\section{T. Davydiuk, S. Syrtseva, V. Endres, V. Nadraga}

of calculation, the company develops independently and prescribes it in accounting policy. Different methods are used to avoid uncertainty in the calculation of the amount that should be recognized as a liability.

In international practice, there are six techniques for calculating underwriting under IFRS.

Conditionally, the methodology can be divided into two groups:

- methods for calculating the amount of the provisions balance at the reporting date;

- methods for calculating the amount of provisions before accrual in the period [14].

Method 1: the amount of provision for warranty is defined as a percentage of revenue from the sale of goods in the most recent reporting period.

This method is most often used in practice and allows you to determine the average amount of the provision.

The percentage is calculated as the ratio of actual warranty costs over a given period to the actual income from the sale of products during the same period. Such a period for the purpose of calculating the percentage in practice is usually from 1 to 5 years.
Guarantee costs for these purposes should be understood not as the amount attributed to the costs for a certain period (sales costs), but the amount directly from the costs incurred in connection with the warranty service (reflected at the expense of the rest of the security and only on top of it - in costs period).

If the entity is just getting started, then the percentage is determined expertly.

As a rule, in practice, the percentage is revised once a year, even if provision is accrued more frequently (quarterly or monthly).

For example, according to the data presented in Table 2, it is necessary to determine the amount of provision to be shown in the balance sheet as of 31.12.19.

Table 2 shows that in 2019 compared to 2018 , there was a sharp increase in sales revenue 2.25 times ( 2450 thousand UAH / 1090 thousand UAH). In this case, the warranty costs have not changed significantly, how much of the warranty cases related to the 2019 sales will occur in the following periods. Therefore, it is logical not to use the last period to calculate the percentage, otherwise we will get an underestimated result: the percentage value drops from $2.12 \%$ to 1.69 percent.

Table 2

Actual indicators of sales revenue and warranty costs of a contingent enterprise over the last 5 years

\begin{tabular}{|l|c|c|c|c|c|c|c|}
\hline \multirow{2}{*}{ Indicators } & \multicolumn{7}{c|}{ Period, years } \\
\cline { 2 - 8 } & $\begin{array}{c}\text { Together for } \\
2015-2019\end{array}$ & 2019 & $\begin{array}{c}\text { Together for } \\
2015-2018\end{array}$ & 2018 & 2017 & 2016 & 2015 \\
\hline $\begin{array}{l}\text { Revenue from sales, thousand } \\
\text { UAH }\end{array}$ & 8390 & 2450 & 5940 & 1090 & 1600 & 1050 & 2200 \\
\hline $\begin{array}{l}\text { Warranty costs, thousand } \\
\text { UAH }\end{array}$ & 142 & 16 & 126 & 21 & 25 & 30 & 50 \\
\hline Percentage, \% & 1,69 & 0,65 & 2,12 & 1,93 & 1,56 & 2,86 & 2,27 \\
\hline
\end{tabular}

Source: conditional data.

Thus, the provision amount will be:

2450 thousand UAH $* 2.12 \%=52$ thousand $\mathrm{UAH}$

As the percentage shows the average share of annual warranty costs in the annual amount of sales revenue, 52 thousand $\mathrm{UAH}$ is, in fact, the annual expected value of warranty costs in 2020.

In practice, using this method the result in most cases is regarded as providing the balance of the reporting date (and not as turnover (charges) for the reporting period). Here it is necessary to pay attention to such a moment. If the warranty period is more than or less than one year, then the calculated balance of the provision is subject to adjustment.

For example, if the warranty period is 18 months, then logically, the balance of the provision as of 12/31/19 should be adjusted:

52 thousand $\mathrm{UAH} * 18$ months $/ 12$ months $=$ $=78$ thousand UAH. 


\section{Methodological aspects of accounting of warranty provision in accordance with international...}

In this case, 52 thousand UAH will be recorded in current liabilities and 26 thousand UAH in long-term liabilities.

If the warranty period is less than a year, then the amount of provision should be adjusted, but only for the smaller side. As the liability on the balance sheet will be overstated at the reporting date and the provision needed to cover the costs only within the warranty period should be recorded.

In order to avoid undervaluing your liabilities, you need to make sure that your accounting policies provide for more often than once a year. For example, if the warranty period is 3 months, it is best to calculate the security quarterly.

If we consider the estimated 52 thousand UAH not as a provision balance as of December 31,2019 , but as the amount of provision accrual in 2019 , there is a need to conduct analytics on the balance of provision for warranties in terms of their accrual periods. In addition to reflecting the accrued amount, you must further adjust the amounts of provision recorded in prior periods as the warranty period expires, as well as in the event of a material change in the percentage used to calculate provision. The calculations will be simpler if the warranty period does not exceed the period over which the sales revenue is multiplied by a percentage to determine the value of the provision. The result will then be the balance of the provision at the reporting date. Accordingly, all prior provision balances (subject to their use) are written off.

Here is an example where the warranty period is 2 years.

The balance of provision as of December 31, 2018 is 18 thousand UAH, including 3 thousand UAH for 2017 and 15 thousand UAH for 2018. In 2019 , warranty costs were incurred in the amount of 10 thousand UAH for goods sold in 2018 and 2 thousand UAH for goods sold in 2019. The provision in 2019 is equal to 52 thousand UAH.

Determine the balance of provisions in terms of goods sold:

- in 2019: 52 thousand UAH - 2 thousand $\mathrm{UAH}=50$ thousand $\mathrm{UAH}$;

- in 2018: 15 thousand UAH - 10 thousand $\mathrm{UAH}=5$ thousand $\mathrm{UAH}$.
The balance of the provisions in terms of goods sold in 2017 in the amount of 3 thousand UAH should be written off, since the warranty period of operation of these goods as of 31.12.19 has expired.

Thus, as of December 31, 2019, in addition to the accumulation of 52 thousand UAH of the provision, which are considered as expected warranty expenses for sales in 2019 , it is necessary to reverse the 3 thousand $\mathrm{UAH}$ of provision charged for sales in 2017.

Together, the balance of the provision as of 31.12 .19 will be 55 thousand $\mathrm{UAH}$, including 5 thousand UAH for 2018 and 50 thousand UAH for 2019.

Therefore, this option is more time consuming and less logical, since the estimated amount of provision (52 thousand UAH) is still the expected amount of warranty costs for a certain period (in our case for 2020), rather than the expected amount of warranty costs associated with goods sold during the settlement period (that is, not the amount of future warranty costs for goods sold in 2019).

It should be noted that in most cases, businesses sell more than one type of product with different warranty periods. In this case, the average weighted warranty period can be calculated.

If there are many contracts, it is possible to select only those that give the main income from the sale in the reporting period and to calculate the average weighted warranty period. However, in practice, often, the share of sales under such contracts with major buyers is no more than $60-70$ percent. In this situation, it is advisable to consider the remaining 30-40 percent when calculating the warranty period.

As a rule, the warranty period does not differ for all other small orders. Accordingly, additional "weighing" can more accurately determine the warranty period.

Method 2: expertly determine a fixed amount for accrual under warranty for a specified period of time. This rule can be enshrined in a separate order. It is inappropriate to indicate this amount in accounting policy, as it is likely to change periodically. Accordingly, you will need to make changes to your accounting policies each time. It is best to indicate in accounting policies that such value will be set and reviewed by individual orders. 


\section{T. Davydiuk, S. Syrtseva, V. Endres, V. Nadraga}

Method 3: if there are several variants of events in which the warranty obligations arise, then the warranties provision is calculated by "weighing" the results of such variants on the probability of their occurrence.

Thus, Table 3 presents information on warranty costs and repair of the basic components of a product in case of their failure, as well as on the probability of such events during the warranty period.

Table 3

Output data for calculating the guarantee on the liability method using the expected cost method (method 3)

\begin{tabular}{|c|c|c|}
\hline Product & $\begin{array}{c}\text { Probability of } \\
\text { failure, \% }\end{array}$ & $\begin{array}{c}\text { The cost of warranty } \\
\text { repair of the basic } \\
\text { part of the product, } \\
\text { UAH }\end{array}$ \\
\hline A & 6 & 2000 \\
\hline B & 4 & 2500 \\
\hline C & 11 & 600 \\
\hline
\end{tabular}

Source: conditional data.

1. It is necessary to calculate the amount of security for guarantee obligations for one unit of goods sold:

$2000 \mathrm{UAH} * 6 \%+2500 \mathrm{UAH} * 4 \%+$ $+600 \mathrm{UAH} * 11 \%=286 \mathrm{UAH}$.

2. It is necessary to calculate the total amount of provision provided for sale, for example 1100 units of goods:

\section{$286 \mathrm{UAH} * 1100$ units $=314600 \mathrm{UAH}$}

Thus, Method 3 can be used for a limited or similar product nomenclature with approximately the same warranty period and if possible to determine the probability a warranty occurrence.

Method 4: The amount of provision for warranties is calculated on a specific object.

In practice, it is advisable to apply this method to single large transactions, which can expertly assess the probability of a warranty event and the potential amount of warranty costs. If there are few such transactions, it will be easy for you to keep track of the accrued amounts until the expiration of the warranty period.

Method 5: Can be used with a limited or similar product range with approximately the same warranty period. In addition, it is necessary to determine the estimated value of the warranty costs based on the income from sales in the reporting period - for each year of operation throughout the entire warranty period.

For example, the warranty period of the product is 2 years. It is empirically (or expertly) determined that the warranty costs: for the first year of operation of the goods make up $2 \%$ of the value of income from its sale; for the second year of operation they make $5 \%$ of the amount of income from its sale.

Revenue from sales for 2017 is 1.5 million $\mathrm{UAH}$, for 2018 - 1.6 million UAH.

As of December 31, 2018, the amount of the provision balance will be:

1.6 million $\mathrm{UAH} * 2 \%+1.5$ million $\mathrm{UAH} *$ * $5 \%=107$ thousand UAH;

If, in 2019, the sales revenue was UAH 1.8 million and the cost of warranty service is 50 thousand UAH. Then the amount of the warranties provision balance on December 31, 2019 will be:

1.8 million $\mathrm{UAH} * 2 \%+1.6$ million $\mathrm{UAH} *$ $* 5 \%=44$ thousand UAH.

Therefore, by this method it is necessary to calculate the amount of the provision at the reporting date.

Method 6: The actual warranty costs for the previous periods is used to calculate the balance of the warranties provision as of the reporting date.

For example, warranty costs for 2018-2019 are 50 thousand UAH and 40 thousand UAH, respectively. The average warranty period is 21 months.

The average monthly amount of warranty costs should be determined:

(50 thousand $\mathrm{UAH}+40$ thousand $\mathrm{UAH}$ ): : $24=3750 \mathrm{UAH}$;

Thus, the balance of the provision amount as of December 31, 2019 will be equal to:

$3750 \mathrm{UAH} * 21$ months $=78750 \mathrm{UAH}$.

When you change sales revenue in different periods, you need to adjust the estimated provisioning amount accordingly. This should be done because the change in sales is reflected in the delayed warranty costs. Therefore, it is incorrect to start from the actual warranty costs for previous periods only.

For example, if the volume of sales in recent periods increases, then the result can be adjusted as 


\section{Methodological aspects of accounting of warranty provision in accordance with international...}

follows. Suppose the average growth rate of sales revenue is $9 \%$ per year.

The monthly average growth rate should be calculated:

$$
9 \%: 12=0.75 \% \text {. }
$$

Next, we calculate the adjusted amount of the provision balance:

$3750 \mathrm{UAH} * 21$ months $*(1+0.75 \%) *$ $* 21=92129 \mathrm{UAH}$

Or: $3750 \mathrm{UAH} * 21$ months $*(1+0.75 \% *$ * 21) $=91153 \mathrm{UAH}$.

It is best to use metrics over several periods to determine the coefficient of change in sales revenue. It is logical to calculate approximately the same number of periods used to calculate the average monthly warranty costs. You can find a relative change in each successive period from the previous one and calculate the average of the results obtained. You can also, for example, summarize sales revenue over the last $\mathrm{N}$ years, as well as sales revenue over the last $(\mathrm{N}+1)$ years, minus sales revenue in the most recent period, and find the relationship between the results obtained.

Method 6 (like method 1) is simple, does not require the use of probabilistic estimates, takes into account the dynamics of income from the sale of goods, so it is often applied in practice.

With regard to all the methods considered, it should be noted that when the warranty period exceeds 1 year, warranties provision in the balance will in most cases be reflected in both current and long-term liabilities.

In this case, it may be appropriate to apply a discount to the long-term component of the provision and to reflect it in a smaller amount with a further increase that will relate to the financial cost. Of course, this should be done if the discount amount is significant.

\section{Conclusions}

The results obtained confirm that the following conclusions and suggestions can be formulated:

1. If the business entity for the goods sold assumes the warranty (legal and / or constructive) and during the warranty period is obliged to eliminate the identified defects at its own expense (to bear the warranty costs), then it becomes obligatory to create provision for warranty in accordance to IFRS. This will allow him not to lower the liability in the balance sheet, evenly distribute the amount of warranty costs over time and put them in the price of the product.

2. It is justified that the seller's warranty can be recognized as a guarantee if all three criteria are fulfilled, namely: the obligation (legal or constructive) must arise as a result of a past event (past event is the fact of sale of goods); repayment will reduce economic benefits; the estimate can be calculated. If at least one of these criteria is not met, then the security is not recognized.

3. The procedure for calculating the value of security in international standards is not specified. The main thing is to consolidate the order of formation of provision for warranties obligations in accounting policy. The accounting policies also need to record the details of the warranty costs under which the provision is created, the frequency of accrual and review of the provision balance, as well as the procedure for adjusting the provision balance as a result of its review.

4. A provision is recognized as an expense for the sale of the period in which it was created. During the reporting period, warranty service costs are recognized at the expense of the balance of previously created provision. If such a balance of provisions is not sufficient, then warranty costs in the amount of excess direct are included in the cost of sales.

5. Recognition of provision implies compliance with the relevant criteria under IAS 37 "Provisions, Contingent Liabilities and Contingent Assets". However, the entry into force of IFRS 15 "Revenue from Contracts with Customers" requires a review of contract provisions based on a five-tiered revenue recognition model. IFRS 15 considers two types of guarantees - assurance-type warranties and service-type warranties. In order to determine the type of guarantee, it is necessary to consider such factors as whether a warranty is required by law, the length of the warranty period, the nature of the tasks that the enterprise promises to perform.

6. The balance will be reflected in the balance in current and/or long-term liabilities, depending on how long the entity provides guarantees - up to or more than one year. 


\section{T. Davydiuk, S. Syrtseva, V. Endres, V. Nadraga}

7. The paper presents 6 methods for calculating a warranties provision under the IFRS financial reporting entities. Conventionally, these methods can be divided into two groups: methods that involve calculating the amount of the balance of the provision at the reporting date; methods for calculating the amount of provision prior to accrual in the period. The first group of methods is easier to apply because it does not require accounting for provision balances by periods of their occurrence. The list of methods considered is not definitive, and other modifications are possible. It all depends on the needs (and capabilities) of the users of the financial statements. When choosing a method, it is necessary to evaluate the complexity, the level of automation, determine the threshold of materiality and then make a decision.

\section{References}

1. Voskalo, N. M., Karyy, O. I., \& Voskalo, V. I. (2017). Features of accounting and reporting in the reporting of information on provision in accordance with national and international standards, as well as the tax code of Ukraine. In Visnyk Natsional'noho universytetu 'L'vivs'ka politekhnika". Seriya "Menedzhment ta pidpryyemnytstvo $v$ Ukrayini: etapy stanovlennya $i$ problemy rozvytku" [Bulletin of National University "Lviv Polytechnic". Series "Management and entrepreneurship in Ukraine: stages of formation and development problems"], 862, 55-60. [in Ukrainian].

2. Demyanenko, S. S. (2015). Peculiarities of accounting of securities in accordance with national standards and international accounting and reporting standards. Hlobal'ni ta natsional'ni problemy ekonomiky - Global and national economic problems, 5, 984-988. [in Ukrainian].

3. Dzyuba, N. (2015). Guarantee service: we account for a new one. In Podatky ta bukhhalters' kyy oblik [Taxes and Accounting], 34, 28-33. Retrieved from https://i.factor.ua/ukr/journals/nibu/2015/april/issu e-34/article-7586.html [in Ukrainian].

4. Zatoka, T. Y. (2011). Disclosure on ways to ensure compliance with reporting obligations: areas for improvement. Mizhnarodnyj zbirnyk naukovykh prats', 2(20), 212-220 [in Ukrainian].

5. Panchenko, O. M., \& Cherevko, A. B. (2016). Improvement of the accounting of provisions and reserves of the enterprise in the conditions of reforming the national economy of Ukraine. Stalyy rozvytok ekonomiky - Sustainable development of the economy, 3, 163-170 [in Ukrainian].

6. Sviridenko, A. (2017). Warranty obligations of manufacturers (sellers). In Podatky ta bukhhalters' kyy oblik [Taxes and Accounting]: 80. Retrieved from https://i.factor.ua/ukr/journals/nibu/2017/october/i ssue-80/article-30951.html [in Ukrainian].

7. Slyvka, Y. V. (2012). Social Responsibility for Product Sales: An Accounting Aspect. Visnyk ZhDTU. 1 (59). 198-203 [in Ukrainian].

8. Chyzhevs' ka, L. V. (2018). Accounting for guarantees in the context of International Financial Reporting Standards. Sotsial'no-ekonomichni problemy suchasnoho periodu Ukrainy. 6 (134). 139-143. [in Ukrainian].

9. Provisions, Contingent Liabilities and Contingent Assets : International Accounting Standard 37. Retrieved from file:///C:/Users/Bosik/Desktop/ viewPdf.pdf.

10. Yehorova, I. Warranty reserve: who should create and what benefits. Retrieved from https://uteka.ua/ ua/publication/commerce-12-sxemy-buxgalterskixprovodok-30-rezerv-na-vypolnenie-garantijnyxobyazatelstv-kto-dolzhen-sozdavat-i-v-chemvygoda.

11. Revenue from Contracts with Customers: International Financial Reporting Standard (IFRS) 15. Retrieved from https://www.pwc.com/vn/en/services/assurance/ ifrs/ifrs-15.html.

12. Vojtenko, T. (2019). Accounting for guarantees under IFRS 15. Podatky ta bukhhalters'kyj oblik. 91. Retrieved from https://i.factor.ua/ukr/journals/ nibu/2019/november/issue-91/article-105341.html.

13. Verkhovna Rada of Ukraine (2010). Tax Code of Ukraine (Order No. 2755-VI, December 2). Retrieved from http://search.ligazakon.ua/l_doc2. nsfllink1/T102755.html [in Ukrainian].

14. Radonov, O. Provisions under IFRS Accounting: 6 Methods of Calculation. Retrieved from https://uteka.ua/ ua/publication/commerce-12-msfo28-obespechenie-pod-garantijnye-obyazatelstva-vmsfo-uchete-6-metodov-rascheta. 